\title{
Monetizing the Debt
}

\author{
Daniel L. Thornton
}

"M images of excessive money stock gromth resulting excessive money stock growth resulting from Federal Reserve purchases of Treasury debt. Many analysts fear that debt monetization may produce undesirable economic consequences, such as mote rapid inflation and, thus, higher nominal interest rates. There appears to be some confusion, however, over what debt monetization means, whether or to what extent the Federal Reserve has pursued a policy of debt monetization in the past and what the best indicator of debt monetization is. These questions are of intense interest, with potentially large deficits looming on the horizon that could put increased pressure on the Federal Reserve to monetize the debt in the future.

The purpose of this article is to clarify the meaning of the phrase "monetizing the debt" and to determine whether the Federal Reserve has monetized the debt since 1960. As we will see, the policy objectives of the monetary authority play an important role in deter. mining whether the Federal Reserve will monetize the debt. We also will show that care must be taken not to confuse debt monetization with growth in the Federal Reserve's portfolio of government debt.

\section{MONETIZING THE DEBT: WHAT DOES IT MEAN?}

In large measure, the phrase "monetizing the debt" grew out of the experience of the Federal Reserve immediately after World War II. At the time, the Federal Reserve had a tacit commitment to the U.S. Treasury to

Daniel L. Thornton is a senior economist at the Federal Reserve Bank of St. Louis. John G. Schulte provided research assistance. stabilize the Treasury ${ }^{+}$s cost of financing the war debt. After the war, individuals began liquidating theit holdings of Liberty Bonds. Because of its agreement with the Treasury, the Federal Reserve purchased substantial amounts of government debt.'

These purchases increased the reserves of the banking system and, consequently, the money stock; the Federal Reserve was said to have monetized the debt. In March 1951, the Federal Reserve and the Treasury reached an accord whereby the Federal Reserve established its independence." Since then, the Fedemal Reserve has been free to pursue its policy objectives independent of the debt financing needs of the Treastzy:"

With the net federal debt (NFD) - total debt minus holdings of government agencies and trusts - at nearly $\$ 1.3$ trillion and with historically high deficits, in both nominal and real terms, there is concern that the rapidly rising debt will put upward pressure on interest rates, inducing the Federal Reserve to in-

\footnotetext{
The Federal Reserve's holdings of government debt more than tripled from 1943 to 1946. See Historical Statistics of the United States (1975), p. 1116

'See Ahearn (1963), pp. 16-21.

${ }^{3}$ Actualty, at a more abstract level, the question of the independence of monetary and fiscal policies is open to debate. Sargent and Wallace (1981) use the government budget constraint to argue that the monetary authority must ultimately monetize deficits. This argument has been challenged recently by Darby (1984), and some evidence has been supplied recently by Barth, Iden and Russek (1984). Furthermore, the budget constraint can be used to arque that the seignorage associated with Federal Reserve open market operations requires a compensatory change in government expend. itures or taxes. This latter point is discussed in Horrigan (1983). The seignorage associated with open market operations is easily illustrated from the budget constraint suggested by Thornton (1984).
} 
crease the money supply more rapidly than it otherwise would or, perhaps, should. ${ }^{*}$

Today, as in the immediate post-World War II period, the phrase "monetizing the debt" means money growth induced by attempts to moderate the effects of rapidly growing government debt on interest rates. By definition, open market operations (buying and selling government securities in the money and capital markets) represent debt monetization, that is, the replacement of government debt with money. Open market purchases and debt monetization, therefore, are often taken to be synonymous." This view is enhanced by the fact that open market operations are usually considered the principal tool through which the Federal Reserve influences the money supply, so that changes in Federal Reserve policy are likely to be reflected initially in its portfolio of government debt. For these reasons, analysts sometimes look at the growth of the Federal Reserve's portfolio of government debt, the ratio of the Federal Reserve's holdings of debt (FHD) to NFD, or similar measures as indicators of debt monetization. These measures, however, give too little attention to the goals of policy and the nature of the money stock mechanism."

It is clear from our definition that debt monetization cannot be analyzed separately from the objectives of Federal Reserve policy. Assume, for example, that the Federal Reserve is targeting money growth to achieve price level stability. Furthermore, assume that real income is growing at a faster rate than velocity so that money growth must be positive. If this money growth is achieved through open market purchases of government debt while the debt is simultaneously increasing, the correlation between the growth in the federal Reserve's portfolio and government debt growth would give the false appearance of debt monetization.' In this example, debt monetization actually occurs

\section{See Tatom (1984) for a historical survey of the deficit.}

In principle, any debt can be purchased. In practice, however, the Federal Reserve primarily purchases marketable debt of the U.S. Treasury.

${ }^{6}$ These measures are singled out here because they are most frequently used in the popular press. Other measures, such as growth of total reserves or the monetary base, suffer from this same deficiency, as well as some of the deficiencies noted in the following discussion. See Blinder (1983), Dwyer (1984) and Barth, Sickles and Wiest (1982) for examples of the various measures that have been employed in empirical studies of this question.

The astute reader will recognize that this implies that open market purchases of debt are not strictly required for debt monetization to occur. This can be argued in a number of ways. At a rudimentary level, assume that the Treasury has the power to print money, so that deficits can be financed either by issuing debi or, as a substitute, printing money. Printing money directly is as much debt mone- only if the Federal Reserve modifies its primary objective of price stability because it fears that debt growth will boost interest rates.

Furthermore, in order to claim that the Federal Reserve has monetized the debt, one would have to argue both that there is a positive relationship between actual or anticipated interest rates and debt growth and that the Federal Reserve had modified its primary money stock growth objective in response to actual or perceived upward pressure on interest rates. In this instance, the association between the difference in the actual and targeted growth rates of money and the growth of NFD would provide evidence of debt monetization. ${ }^{*}$ Thus, using the growth of FHD or the ratio of FHD to NFD alone as indicators of debt monetization could be misleading. If the Federal Reserve achieves its desired money growth objective, it is not monetizing the debt, even if money growth is achieved solely through open market purchases of government debt.

Alternatively, suppose the Federal Reserve's intermediate policy objective is to peg interest rates at some desired level." Then the Federal Reserve monetizes the debt only when changes in the debt, ceteris paribus, produce changes in interest rates in the same direction. That is, if increases in the debt put upward pressure on interest rates, the Federal Reserve will monetize the debt under an interest rate target.

\section{OBSTACLES TO IDENTIFYING DEBT MONETIZATION}

In addition to the need to account for the explicit or implicit targets of monetary policy, there is another consideration that makes the growth of FHD, the ratio

tization as if debt were first issued to finance the deticit, then repurchased (later) through note issue.

Ot course, the Treasury cannot issue notes directly. Indeed, the Federal Reserve cannot even purchase government debt directly from the Treasury. Consequently, all deficits must initialiy be financed through debt issue. This initial debt issue increases the demand for credit. If this drives interest rates upward, the Federal Reserve can lessen the effect by increasing the supply of credit, using any of its policy tools. The long-run effects of Federal Reserve activities, however, depend on the tool used due to possible wealth effects and the seignorage associated with open market operations. See Thornton.

'This does not imply that the Federal Reserve has the ability to hit its money target exactly, It requires onty that there be a systematic relationship between these errors and debt growth. The identification of this process could be complicated, however, if the unintentional errors are associated directly or indirectiy with debt growth.

IIt is difficult to conceive of a situation in which the Federal Reserve could control interest rates in anything but the short run; nevertheless, this is a common conception of the iransmission mechanism of monetary policy. 
of FHD to NFD and similar measures even less reliable as indicators of debt monetization: money growth does not necessarily require growth in the Federal Reserve's portfolio of governmeot securities. Thus, the link between debt monetization and the growth of FHD may be much weaker than commonly imagined.

Consider the simple model of money growth,

$$
\dot{\mathrm{M}}=\dot{\mathrm{m}}+\dot{\mathrm{B}} \text {, }
$$

where the growth of money, $\dot{M}$, is the sum of the growth of the money multiplier, m, and the growth of the adjusted monetary base, $\dot{B}$. If adjusted base growth were achieved entirely through open market operations and if the muttiplier were constant (i.e., $\dot{m}=0$ ), money growth would be equal to the growth in the Federal Reserve's portfolio of government debt. If the multiplier were rising, however, money growth would exceed portfolio growth; if the multiplier were falling, portfolio growth would exceed money growth. Therefore, the extent to which the Federal Reserve is monetixing the debt cannot be determined simply by observing the growth rate of the Federal Reserve's portfolio of government securities. Multiplier movements must be considered because such movements weaken the link between portfolio growth and debt monetization.

\section{Base Growth and Debt Monetization}

Other factors affect the link between adjusted base and portfolio growth and, thereby, make the connection between debt monetization and the growth of the Federal Reserve's portfolio even more tenuous. Even if the multiplier is constant, the growth rate of money need not correspond closely with growth in the Federal Reserve's holdings of government debt.

One of these factors is changes in reserve requirements, such as those mandated by the Monetary Control Act of 1980. These reserve requirement changes are reflected in the reserve adjustment magnitude (RAM). ${ }^{19}$ Increases in RAM increase the base, while reductions reduce it Consequently, changes in RAM may cause the Federal Reserve to buy more or less government debt than it otherwise would to achieve its monetary growth objective under a monetary tar geting procedure.

Adjusted base growth also is affected by other factors, such as depository institution borrowing from

10 See Tatom (1980) for a discussion of the adjusted monetary base and $\mathrm{AAM}$. the Federal Reserve and Federal Reserve float." Secular movements in these factors can result in adjusted base growth that is faster or slower than the growth of the Federal Reserve's portfolio. Consequently, data on the growth rate of the Federal Reserve's portfolio is not necessarily a good indicator of the extent to which the Federal Reserve is monetizing the debt.

\section{An Illustration of These Relationships}

The importance of these factors is illustrated in charts 1-4. Chart 1 shows the ratio of FHD to NFD annually from 1960 to 1983 . This ratio increased from 1960 to 1974 and declined thereafter. Thus, generally speaking, the Federal Reserve purchased government securities at a more rapid pace than the growth of NFD up to 1974, but at a much slower pace afterwards. If this ratio were used as the sole indicator of debt monetization, one would likely conclude that the Federal Reserve monetized the debt from 1960 to 1974 , then reversed this policy.

The same conclusion would emerge if only the growth rate of the Federal Reserve's portfolio were considered." Yet M1 growth was about 4.8 percent during the former period and about 7.2 percent during the latter period. Thus, the growth of money was slower in the first period than in the second despite the fact that growth of FHD was faster in the first period than in the second, both in absolute terms and relative to the growth of NFD.

This inverse relation can be explained, in large part, by movements in the money multiplier, RAM, deposi* tory institutions' borrowings and float. These series are presented in charts $2-4$.

The multiplier declined more or less steadily through 1974. Over the same period, RAM was fairly stable, first rising then dropping slightly. Borrowing was fairly stable through 1972, then increased dramatically in 1973-74. Float increased modestly through 1972 , then declined by about $\$ 1$ billion during 1973 and 1974. On net, a modest amount of monetary base was supplied to the banking system from 1960 to 1974 through borrowings and float, while RAM drained a modest amount of monetary base from the system over this period. With the exception of borrowings during 1973-74, however, none of these factors was

\footnotetext{
"There are other factors that affect base growth; however, quantitatively they are typically less important than those noted.

12The compounded annual rate of growth of FHD was 6.89 percent from 1974-83, compared with 8.23 percent from $1960-74$.
} 
Chart 1

\section{Ratio of Federal Reserve Holdings of Federal Debt to Total Debt}

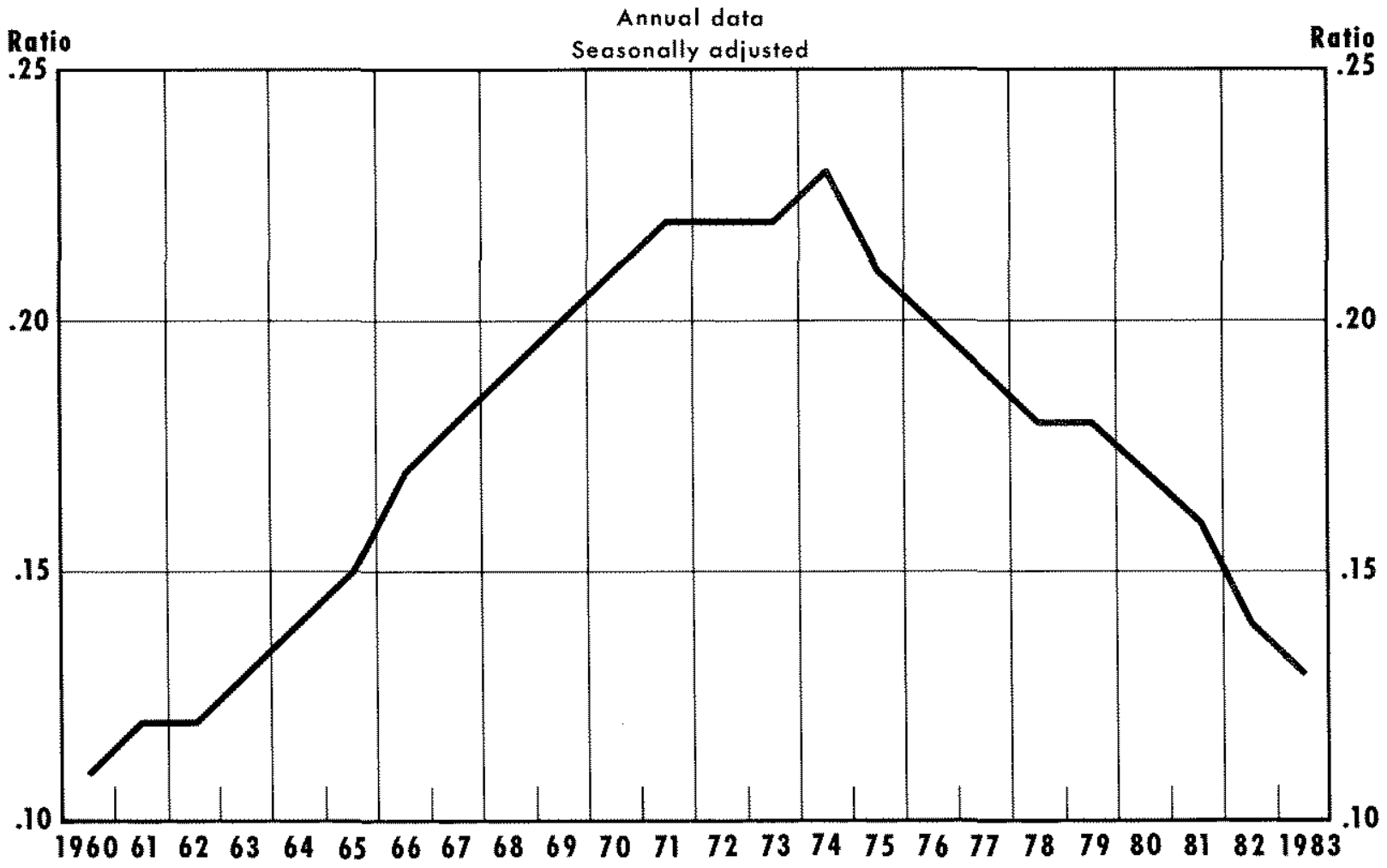

particularly large relative to the decline in the multiplier. ${ }^{1: 3}$

Consequently, even if the policy objective had been zero money growth, the Federal Reserve still would have had to make substantial net open market purchases of government securities to offset the decline in the multiplier. Thus, the increase in the ratio of $\mathrm{FHD}$ to NFD might reflect nothing more than the Federal Reserve's need to make punchases of government debt (to offset multiplier movements) in excess of the growth of NFD over this period.

After 1974, a number of factors reduced the Federal Reserve's need to engage in open market purchases. There was a significant increase in RAM through 1974 78, followed by an even more dramatic rise after the

${ }^{13}$ For example, the multiplier declined from 3.13 in 1960 to 2.78 in 1974. Given the average level of the adjusted monetary base of $\$ 64.82$ billion over this period, the decline in the muttiplier had an impact equivalent to a $\$ 7.64$ billion drain on the adjusted monetary base on average over this period.
Monetary Control Act of 1980 . At the same time, both borrowings and float increased dramatically through 1975-79, then declined through 1983. While the multiplier continued to decline through 1980 , the rate of decline was more moderate than before. Since 1980 , the multiplier has remained relatively unchanged. It is easy to see how money growth could have accelerated since 1974 even though the ratio of FHD to NFD has fallen. ${ }^{-}$Thus, the growth of FHD could be used as an indicator of debt monetization only if these other factors affecting money remain unchanged.

4No attempt is made here to explain why the various changes in the multiplier, RAM, the float or borrowings occurred. Nevertheless, some of these changes can be readily explained. For example, the increase in borrowings in 1974 was due, in part, to the Federal Reserve's efforts to shore up the banking system after the collapse of the Franklin National Bank (see the Board of Governors of the Federal Reserve System [1974), pp. 740-41). Likewise, the significant jump in RAM after 1980 can be attributed directly to the Monetary Control Act of 1980, while the significant decine in the float after 1979 is associated with Federal Reserve efforts to improve the check-clearing process. 
Chort 2

\section{Money Multiplier}

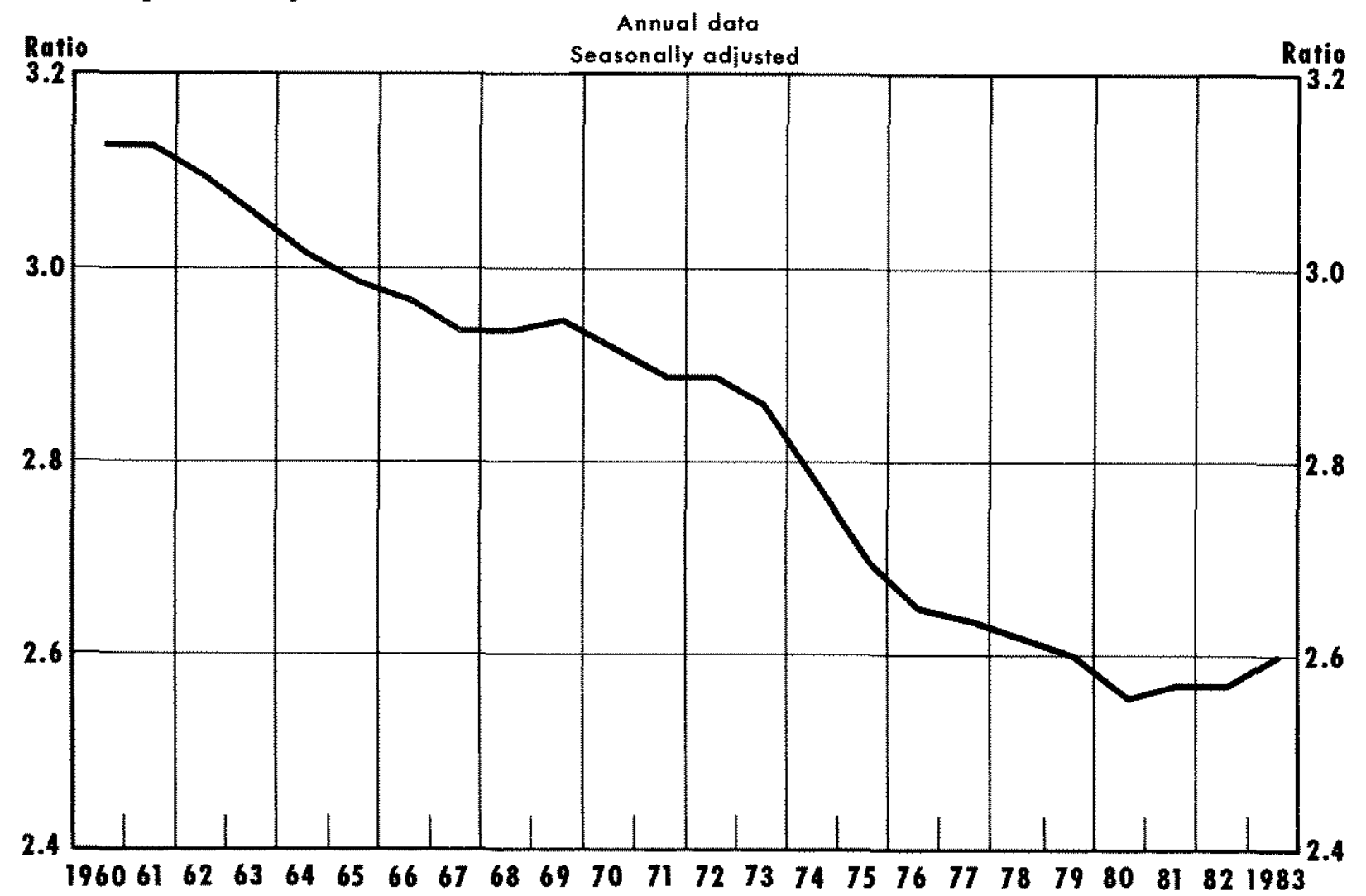

Actually, it would be legitimate to use the growth of the FHD as an indicator of debt monetization if the Federal Reserve established it as an intermediate policy target. Since this has never been done, the possibility is not considered here.".

\section{A Note on the Interest Rate and Liquidity Effects}

The reader is cautioned that this analysis is an illustration of debt monetization under the usual textbook description of countercylical monetary policy. As such, it and the empirical analysis that follows are heavily dependent on the existence of two effects that find little support in empirical studies. ${ }^{\text {"i }}$ The first is the effect of changes in the government debt on interest

\footnotetext{
${ }^{15}$ During the period from October 1979 to October 1982, the Federal Reserve used nonborrowed reserves as an operating target. Money growth, however, was its intermediate policy target.

${ }^{16}$ For evidence on the liquidity effect, see Brown and Santoni (1983). Melvin (1983) and the references cited in these articles. For evidence on the relationship between debt growth and interest rates, see Evans (1984), Blinder and the references cited in Binder.
}

rates. The story of debt monetization told above rests on the idea that increases in debt issue by the Treasury raise the demand for credit relative to the supply; consequently, interest rates rise. While it is beyond the scope of this article to delve into these arguments, some economists believe, and the bulk of empirical work suggests, that increases in debt have no effect on interest rates. If this is true, then increases in debt would not put pressure on the Federal Reserve to monetize under any policy regime - unless, of course, the Federal Reserve believes that debt increases cause interest rates to rise.

The second effect implicit in this analysis is the socalled liquidity effect, an initial decline in interest rates associated with an unexpected acceleration in the growth rate of money. While the liquidity effect has been isolated empirically, estimates suggest that it is weak and short-lived. The evidence further suggests that the longer-run effect of accelerated money growth is higher, not lower, nominal vates of interest. If the Federal Reserve believed this, it would be considerably less anxious to monetize debt increases, re- 
Chart 3

Reserve Adjustment Magnitude (RAM) and Float at Depository Institutions

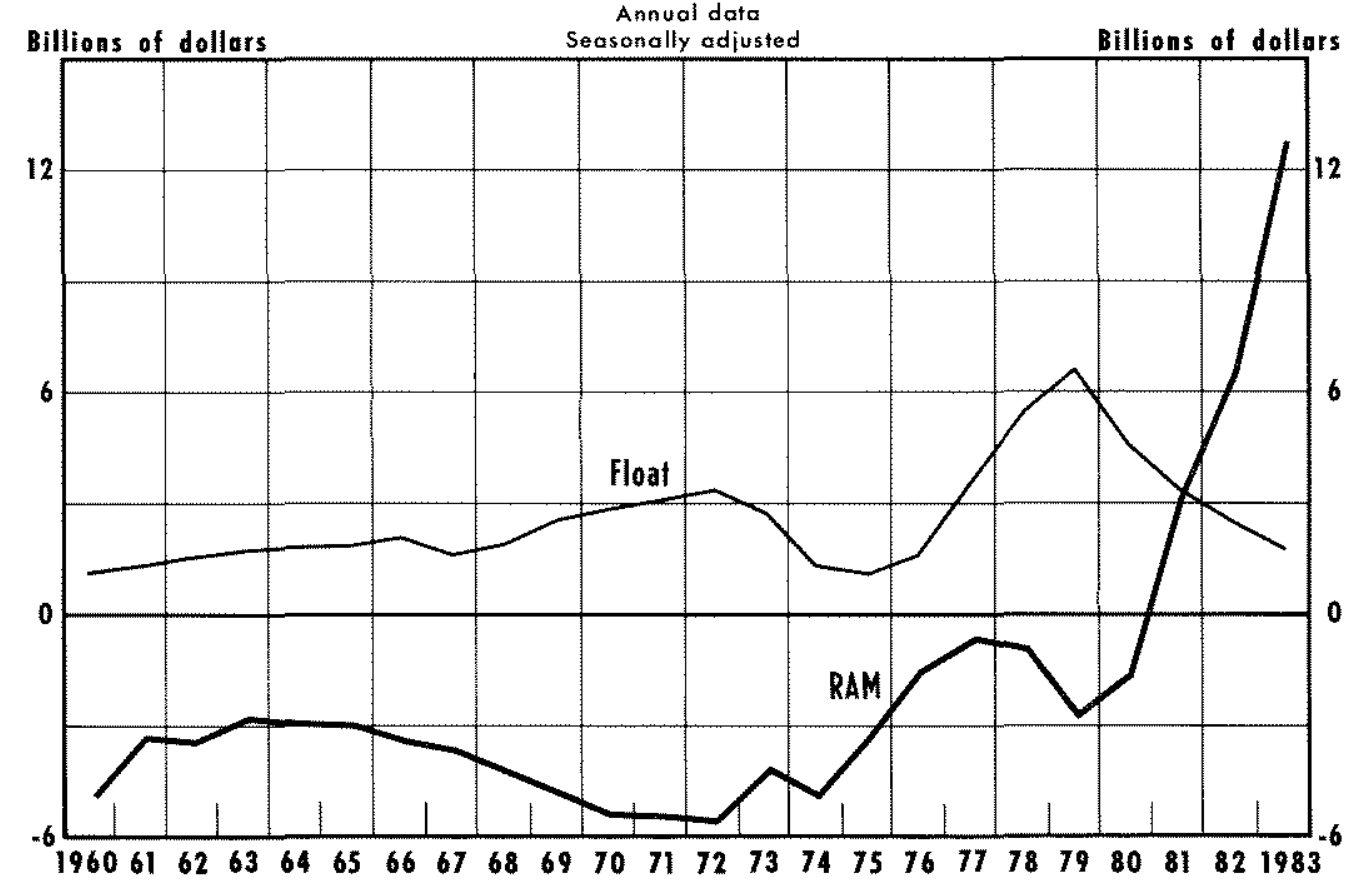

Chart 4

Total Borrowings at Federal Reserve Banks

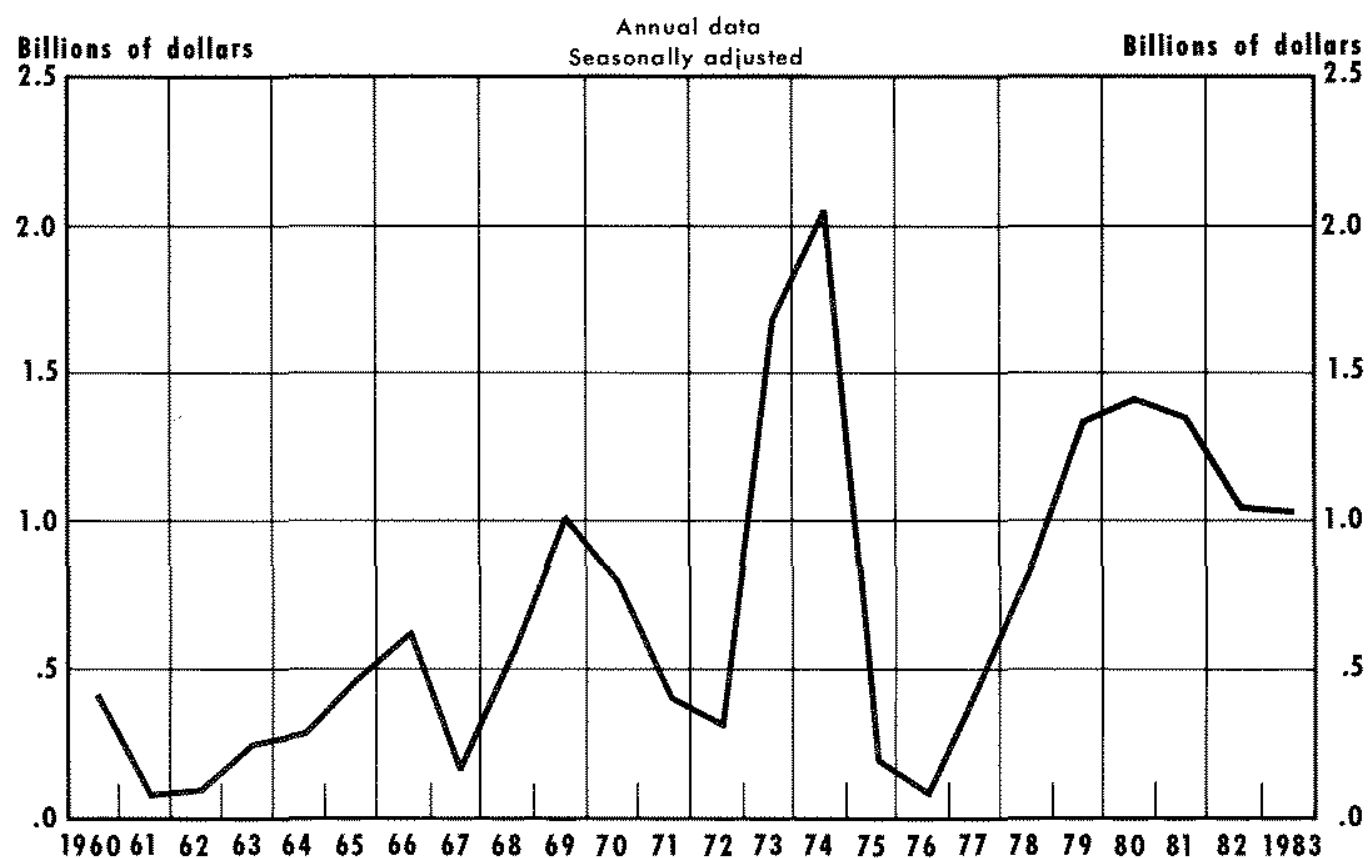


alizing that the longer-run consequences of its actions would be higher inflation and higher nominal interest rates.

\section{WHAT IS THE EVIDENCE ON DEBT MONETIZATION?}

Ideally, to determine whether the Federal Reserve has monetized the debt, deviations between actual and desired monetary targets (say money growth) should be compared with debt growth. Practical considerations make such a comparison difficult. If the Federal Reserve established target rates for the growth of money that were changed infrequently, the growth rate of money might represent a useful proxy for the deviations between actual and desired money growth. Unfortunately, during most of the post-accord experience with countercyclical monetary policy, the evidence suggests that the Federal Reserve seldom focused exclusively on a monetary aggregate target.

Instead, the Federal Reserve has given considerable emphasis to interest rates as the primary intermediate policy target. Only during the past 15 years has the Federal Reserve given monetary aggregates much explicit attention. In January 1970, the Federal Open Market Committee (FOMC) expressed a desire to place increased emphasis on the growth of certain monetary aggregates, but explicit targets for the aggregates were not established until 1975. From October 1979 to October 1982, the FOMC emphasized the growth of the monetary aggregates even more; however, the weight given to the various aggregates changed over this period. Consequently, it is difficult to find an extended period over which monetary policy objectives are sufficiently stable to draw strong inferences about whether the Federal Reserve has monetized the debt. Despite these difficulties, we provide some evidence, which should be regarded as descriptive, of the relationship between money growth and debt growth during the past two and one-half decades.

The empirical investigation undertaken here differs from the usual procedure, which is to estimate a "Fed" eral Reserve reaction function." "The reaction function is an equation that presumably represents the Federal Reserve's response to variables affecting its policy decisions. Studies that have used this type of equation have produced inconclusive results and suffer from two problems."

77For a more precise definition and a review of some of the empirical literature, see Dwyer. For other reviews of empirical studies, see Blinder and Barth, Sickles and Wiest.
First, many of these studies have used reserve or base growth as the monetary policy variable. Since the evidence suggests that the Federal Reserve has never targeted explicitly on these variables, changes in the growth rates of these variables should not be relied on to provide evidence of debt monetization.

Second, these studies include only contemporaneous values of both the monetary policy variable and the measure of federal debt growth. Since these variables are considered only simultaneously, it cannot be detemined whether monetary growth causes debt growth or vice versa. The causation running from money to debt is likely because money growth affects prices, output and nominal interest rates which, in tum, feed back to debt growth. ${ }^{\text {I* }}$ Of course, no statistical procedure can establish causality. There is an easily implemented procedure, however, which can be used to test for the temporal ordering of two or more variables. The procedure is called a test of Granger causality:

\section{The Test Procedure}

This test procedure can be illustrated by using the growth rate of $\mathrm{M}$ and $\mathrm{NFD}$. Let $\dot{\mathrm{M}}_{1}$ and $\mathrm{NFD}$, denote the growth rates of money and the net federal debt, rew spectively, in the current period and let $\dot{\mathrm{M}}_{t-2}, \dot{\mathrm{M}}_{1-2}, \ldots$, $\mathrm{NFD_{1-1 }}, \mathrm{NFO}_{1-x,}, \ldots$, denote values of these variables in previous periods. The test for Granger causality running from $\dot{M}$ to $N F D$ amounts to regressing the current value of $N \dot{F} D$ on past values of itself and $\dot{M}$, and testing the hypothesis that all of the coefficients on the past values of $\dot{\mathrm{M}}$ are zero. To test that Granger causality runs from NFD to $\dot{M}$, the current value of $\dot{M}$ is regressed on previous values of itself and $\mathrm{NFD}$, and the hypothesis that the coefficients on the past values of NFD are zero is tested. If the latter hypothesis is rejected, while the former is not, then it is said that growth of the NFD Granger-causes (temporally precedes) money growth. If the former is rejected, while the latter is not, then money growth is said to Grangercause (temporally precede) growth of the NFD. If both are rejected, no temporal ordering can be established (i.e., there is feedback between $\dot{M}$ and NFD). If neither can be rejected, the series are not temporally related (i.e., they are said to be independent).

\footnotetext{
rasee Dewald (1984), Cartson (1984) and footnote 3.

19Friedman and Schwartz (1963) were among the first to try to estab lish the temporal ordering between macroeconomic variables. Despite its name, it is now recognized that this procedure is not literally a test of causality, nor is it a test of statistical exogeneity. See Zellner (1979) for a discussion of causality, and see Jacobs, Leamer and Ward (1979) and Wu (1983) for a discussion of the relationship between Granger causality and statistical exogeneity.
} 
Tests of Granger causality were performed over the 1/1960-IV/1983 period using two measures of debt growth that have been used in the reaction function literature. The first is the growth of NFD, discussed earlier. The second is the high-employment budget deficit (HEBD)." The deficit and changes in the NFD differ by the so-called off-budget items. These items are omitted from the official reports of the deficit, despite the fact they require debt issue.

In addition, the changes in the NFD and the HEBD differ in that the latter is adjusted for cyclical factors, while the former is not. Consequently, changes in NFD may mistepresent the pressure to monetize the debt because they are not cyclically adjusted. In other words, a given change in NFD is likely to be associated with a much smaller effect on interest rates if it occurs in the contraction rather than the expansion phase of the cycle.

Furthermore, since a relatively larger portion of deficits are cyclically induced, these cyclical influences may be dominant." If these cyclically induced changes in debt are not associated with rising interest rates, there is no pressure to monetize the debt. Thus, because the cyclical effects have not been controlled for, there may be no temporal ordering running from NFD to money. Changes in money growth, moreover, have been shown to induce cyclical swings in economic activity, so we should not be surprised to find a strong effect running from money to income to NFD. To account for the effects of cyclical factors, lags of output growth and lags of the inflation rate are included in some of the tests of Granger causality.

The advantage of using the $\mathrm{HEBD}$ is that it is adjusted directly for cyclical factors. It too may misrepresent the pressure to monetize the debt, however, because the off-budget items are omitted. Consequently, it may be significantly smaller than the amount of debt

\footnotetext{
20The data for HEBD ends in III/1983, so the tests of Granger causality involving this variable were performed over this shorter period. Although there are other ways to carry out these tests, work by Geweke, Meese and Dent (1983) and Guilkey and Salemi (1982) indicate that the procedure used here is preferred.

${ }^{2 \text { S }}$ See Tatom (1984).

${ }^{22}$ Lags of past intation are included based on the finding reported by Blinder and on the work of Horrigan and Protopapadakis (1982) and others who tind that much of the measured deficits are related directly to intation. It could also be argued that the lag from money growth to inflation is long. Theretore, the lags of past inflation may simply be a proxy for even longer lags of money growth.
}

In addition to NFD, a relatively new measure, the cyclically adjusted federal debt calculated by deLeeuw and Holloway (1983), was used. The qualitative results with this variable were unchanged from those using NFD, so they are not reported here. issue. ${ }^{33}$ Furthermore, since the HEBD is cyclically adjusted, changes in past output should not affect tests of Granger causality running from money to HEBD; past changes in prices, however, may affect these tests.

Finally, because the question of debt monetization is tied closely to the policy objectives of the Federal Reserve, it is important to take account of these policy objectives. Thus, the tests of Granger causality were conducted over the entire period I/1960-IIL/1983 and over the subperiod III/1972-11//1983, during which at least some consideration was given to money stock objectives. ${ }^{24}$ Because of the shortness of this period, it was necessary to restrict the search to six lags on each variable and to include only three lags of output growth and inflation.

\section{Empirical Results}

The Granger causality tests were performed on quarterly growth rates of M1 and NFD and on the quarterly growth rate of $\mathrm{M1}$ and HEBD, following a procedure outlined in Thornton and Batten (1985), ${ }^{25}$ The significance levels corresponding to the calculated F-statistics of the Granger tests are reported in tables $1-6^{-36}$ The significance levels are presented because the significance of the $F$-statistics vary with the

23For example, the change in NFD in fiscal 1983 of $\$ 202.8$ bittion was made up of a $\$ 188.8$ billion on-budget deficit and a $\$ 14.0$ billion offbudget deficit. See Economic Report of the President (1983). Also, see Allen and Smith (1983).

${ }^{24}$ The FOMC stated its desife to place increased emphasis on certain monetary aggregates at its January 1970 meeting; however, the estimation period begins in III/1972 to be conservative and to allow for the six lags of both variables.

${ }_{25}$ The fact that these tests ignore the question of whether changes in the debt affect market interest rates is particularly important in interpreting the results. If changes in debt have no effect on interest rates, we should not expect to find a temporal ordering running from debt growth to money growth. If changes in debt have an effect, we may or may not find such a temporal ordering. Thus, the lack of a temporal ordering running from debt to money growth could result either from a lack of an interest rate effect or from a refusal on the part of the Federal Reserve to monetize the debt.

Futhermore, in a rational expectations view, the Federal Reserve might anticipate the deficit and increase money growth in advance of the actual increase in the debt. In this case, money growth might precede debt growth, but we find no evidence of this temporal ordering.

${ }^{26}$ Tests of Granger causality should be conducted with time series that are covariance stationary. When the autocorrelation functions of $\dot{M} 1, N F D$ and HEBD were investigated, the series appeared stationary. When the Granger causality tests were undertaken including a time trend, however, the trend variable was always significant at the 5 percent level, suggesting that the series are not stationary. When the tests were performed on first differences of $M 1, N F D$ and HEBD, the time trends were uniformly insignificant. With one exception noted below, however, these results were not qualitatively different from those using the growth rates of M1 and NFD and the level of HEBD. The latter results are reported because they are easier to interpret. 


\section{Table 1}

\section{Significance Levels for Granger Causality Tests of Mi1 on NFD for the 1/1960-1V/1983 Period}

\begin{tabular}{|c|c|c|c|c|c|c|c|c|c|c|c|c|}
\hline \multirow[t]{2}{*}{ lags or $W_{1}$} & \multicolumn{9}{|c|}{ 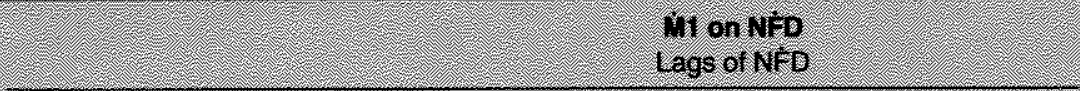 } & \multirow[b]{2}{*}{10} & \multirow[b]{2}{*}{1} & \multirow[b]{2}{*}{12} \\
\hline & T & 2 & 8. & 4 & 5 & 6 & 7 & 8 & 9 & & & \\
\hline 1 & 074 & 685 & 1060 & 089 & 124 & 100 & 269 & 264 & 289 & 260 & 910 & 332 \\
\hline 2 & 080 & 041 . & 648 & 084 & 18 & 202 & 283 & 275 & 285 & 27 & 3.5 & 338 \\
\hline 6 & 002 & 041 & $647 \%$ & $\operatorname{0g} 1$ & 121 & 167 & 268 & 257 & p pro & 266 & 508 & 819 \\
\hline 4 & 221 & 156 & 169 & 269 & $34 \%$ & 465 & 566 & 580 & 779 & 514 & 566 & 589 \\
\hline 5 & 061 & 068 & $1 / 10$ & 79 & 205 & 648 & 396 & 355 & 306 & 349 & 407 & 422 \\
\hline 6 & 088 & 059 & 095 & 165 & 204 & 329 & 892 & 369 & 822 & 666 & 425 & 440 \\
\hline 7 & 276 & 204 & 321 & 48 & 609 & 726 & 756 & 745 & 758 & 748 & 74 & 79 \\
\hline 8 & 318 & $2 / 4$ & 8.88 & 508 & 681 & 747 & 778 & 760 & 779 & 766 & 705 & 798 \\
\hline 9. & 16 & $2 \pi$ & 867 & 498 & 636 & 757 & 689 & 614 & 630 & 828 & 062 & 670 \\
\hline 10 & 208 & 269 & 886 & 528 & 662 & 79 & 826 & 606 & 858 & 840 & 800 & 897 \\
\hline 1 & 2130 & 255 & 401 & 562 & 680 & 785 & 6.2 & 640 & 651 & 805 & 860 & 900 \\
\hline 12 & 208 & 247 & (298 & 504 & 667 & 765 & 636 & 628 & 846 & 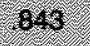 & 861 & 898 \\
\hline Irgs on NII) & & & & & & VII & $M m_{11}$ & & & & & \\
\hline & 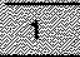 & 2 & 8 & 4 & 5 & 6 & 7 & 8 & g. & 10 & 17 & 12 \\
\hline 1 & 249 & 511 & 000 & $000^{\circ}$ & 600 & 600 & 600 & $800^{\circ}$ & 000 & 000 & 600 & $600^{\circ}$ \\
\hline 2 & 2410 & 510 & 000 & 000 & 6006 & (000\% & 000 & 000 & $600 \%$ & 600. & 604 & $001 \%$ \\
\hline a. & 195 & 420 & 000 & 600 & 000 & $000 \%$ & $00)^{\circ}$ & 000 & 000 & 600 & 601 & 001 \\
\hline 4 & 241 & 502 & 002 & 008 & $001 \%$ & 000 & 000 & 000 & 000 & 001 & 0102 & 008 \\
\hline 5 & 245 & 509 & 1001 & 090 & 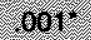 & 000 & 600 & 000 & 000 & 1001 & 0082 & 002 \\
\hline 6 & 254 & 517 & 0015 & 000 & $001 \%$ & 000 & 000 & $000^{\circ}$ & $00 \%$ & 001 & 602 & 006 \\
\hline 7 & 246 & 509 & 601 & 0.01 & ogl & 000 & 000 & 1000\% & 001 & 001 & 606 & 003 \\
\hline 9 & 253 & 519 & 1002 & 601 & 001 & 000) & 001 & 000 & 001 & alop & 106 & 004 \\
\hline 9 & 800 & 570 & ope & 001 & 002 & 000 & 000 & 001 & 001 & 003 & 015 & 006 \\
\hline 10 & 837 & 616 & 1008 & bot & 1002 & 000 & 000 & 001 & 002 & 004 & 1006 & 008 \\
\hline 11 & 462 & 757 & 602 & 001 & 601 & 000 & $00 \%$ & 000 & 001 & $00 \%$ & 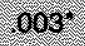 & $003^{2}$ \\
\hline 12 & 430 & 7.34 & 1002 & 001 & 001 & 000 & 900 & 000 & 001 & 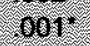 & 002 & 002 \\
\hline
\end{tabular}

degrees of freedom. The outcomes that are significant at the 5 percent level are denoted by an asterisk. For example, in the regression of $\dot{M} 1$ on $\mathrm{NFD}$ in table 1 the entry for three lags on each variable is .047 . This indicates that the hypothesis that NFD does not Grangercause $\dot{M} 1$ can be rejected at the 5 percent significance level for this lag specification. When the lag length is increased to four, however, this hypothesis cannot be rejected because the entry, 269 , is greater than .05 .

The significance levels based on simple bidirectional tests of Granger causality between $\mathrm{M} 1$ and NFD and $\dot{M} 1$ and HEBD are presented in tables 1 and 2 , respectively. The results in table 1 indicate a strong unidirectional effect running from $\dot{M} 1$ to NFD. Ony seven of the $144 \mathrm{~F}$-tests for the influence of $\mathrm{NFO}$ on $\mathrm{M} 1$ reported were significant at the 5 percent level. None of these seven lag structures, however, was chosen by a commonly used lag-length specification criterion. ${ }^{2 z}$ Because NOD is not cyclically adjusted and is likely to be affected by changes in real output and prices induced by changes in the money supply, it is not too surprising that the temporal ordering runs from $\dot{\mathrm{M}} 1$ to NED. ${ }^{2 *}$

${ }^{27}$ The lag-length selection criterion used here is the final prediction error. See Thornton and Batten, and Batten and Thornton (1984).

zalt is somewhat surprising, however, that the same qualitative result is obtained for the cyclically adjusted debt measure. This suggests the possibility that this cyclically adjusted measure does not capture all the effects of past output and price level growth. This conjecture is supported by the fact that the significance levels are greatiy increased when three lags of output growth and inflation were included in these specifications. In any event, there is no evidence of a temporal ordering running from cycilcally adjusted debt to money. 


\section{Table 2}

\section{Significance Levels for Granger Causality Tests of M1 on HEBD for the [/1960-111/1983 Period}

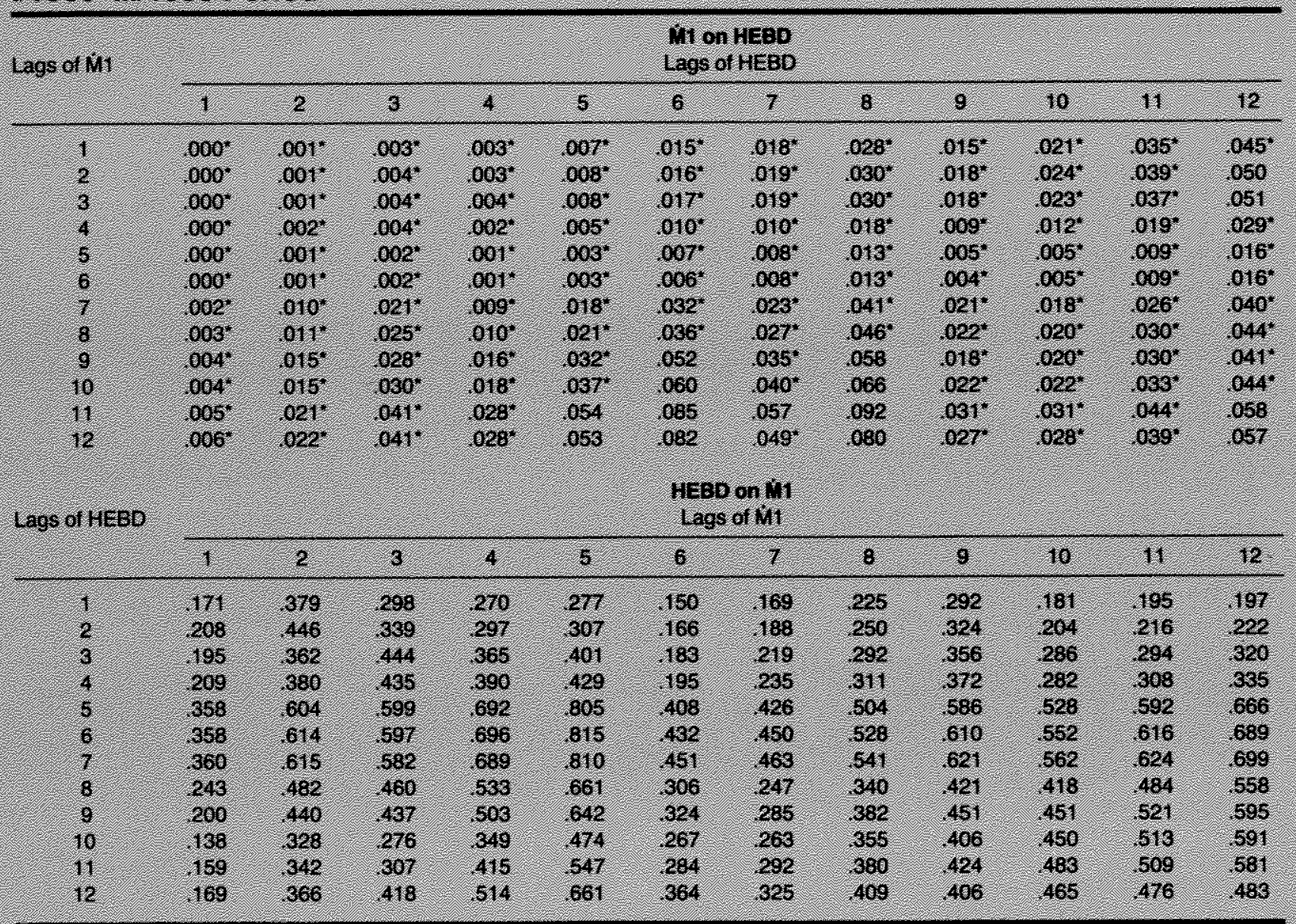

indicales signifeance al the 5 percent lovel

The results in table 2 for the HEBD, however, indicate unidirectional causality running from HEBD to $\dot{M} 1$. The hypothesis that HEBD has no impact on M1 was rejected for nearly every lag specification considered, while the hypothesis that $\dot{M} 1$ has no effect on HEBD was never rejected. Thus, this measure suggests that money growth responds to cyclically adjusted changes in the debt.

\section{The Granger Tests Extended for Cyclical Influences}

In the simple tests of bivariate Granger causality presented above, the observed feedback between money growth and NFD or the causality running from HEBD to $\dot{M} 1$ could be the result of the close association between these variables and factors not ac- counted for by the equation. In order to guard against this possibility, the tests were repeated adding three and then six lags of the growth rates of prices and real output as additional variables. ${ }^{29}$

The results for the equations with six lags are presented in tables 3 and 4 . The results in table 3 indicate

${ }^{29}$ The possibility that money growth responds to either past output growth or inflation can be argued two ways. First, such variables could represent a Federal Reserve reaction function response, e.g. high past rates of inflation or output growth induce the Fed to slow the rate of $M 1$ growth. Second, the money supply could be endogenous (at least over short periods of time like a quarter), i.e., related to other variables in the system like interest rates. Since interest rates are positively related to both inflation and output growth, the money stock should move with these variables. If the second case were correct, there should be a positive relationship between past inflation and money growth; however, Blinder reports a negative rela. tionship. We find the same result, although it is not reported here. 


\section{Table 3}

\section{Significance Levels for Granger Causality Tests of M1 on NFD for the $1 / 1960-1$ V/1983 Period, with six lags of $\dot{P}$ and $\dot{X}$}

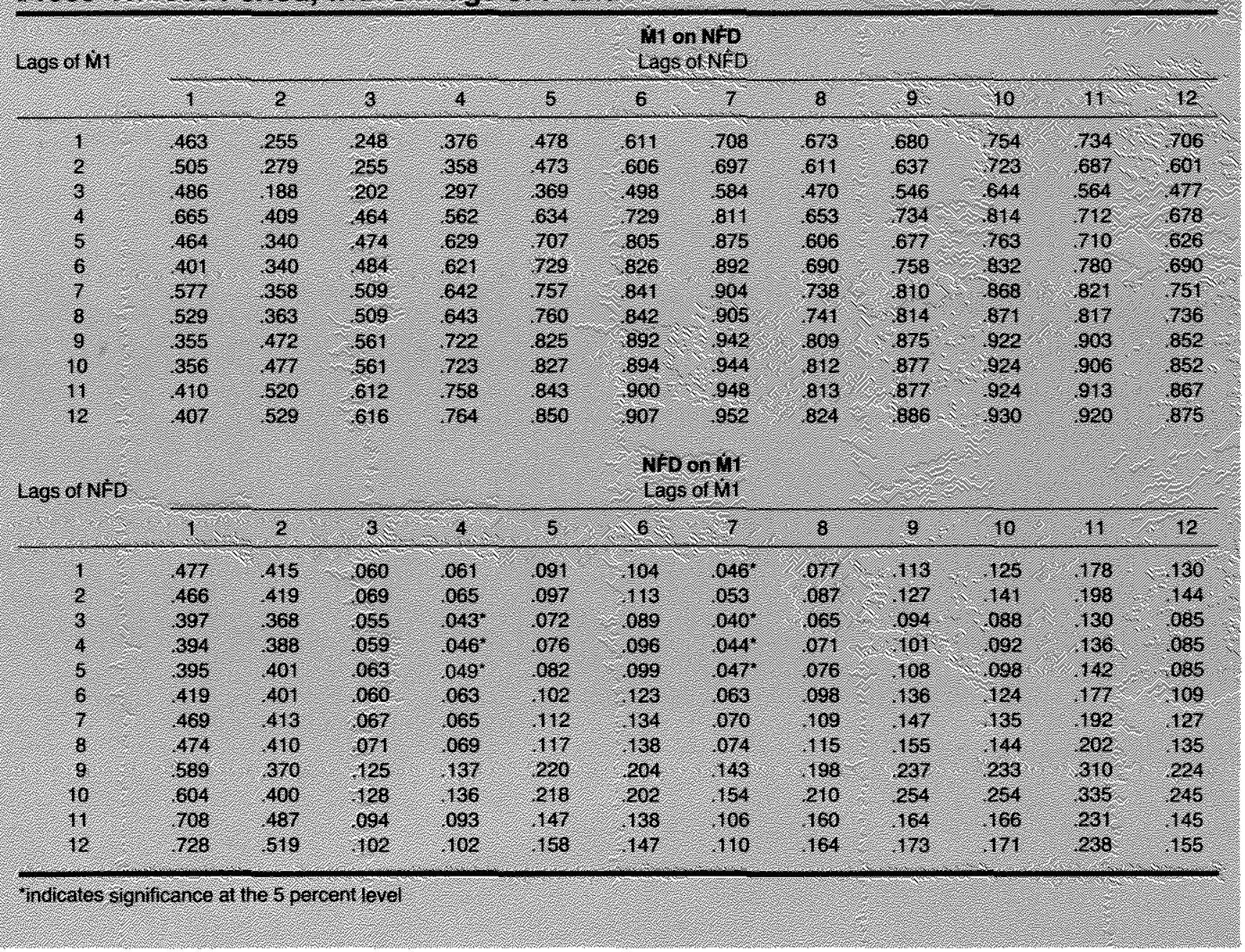

that $\dot{M} 1$ and NFD are independent series. There are just seven instances where the $\mathrm{F}$-tests of $\mathrm{NFD}$ on $\dot{\mathrm{M}} 1$ are significant, and none of these were selected by the lag-length specification criterion. ${ }^{30}$ Thus, ance output growth and inflation are accounted for, there is virtually no evidence of a separate effect of money growth on debt growth and no evidence of causality from $\mathrm{NF} D$ to $\dot{\mathrm{M}} 1$

The results in table 4 are similar to those in table 2, in that $\dot{M} 1$ has no effect on HEBD, while HEBD continues to Granger ${ }^{*}$ cause $\dot{M} 1$. A comparison of tables 2 and 4, however, shows that the significance levels for

3owhen first differences of growth rates are used, there is no area of the lag space where the hypothesis can be rejected. the tests of the effect running from HEBD to $\vec{M} 1$ are substantially larger when growth rates of output and prices are accounted for. Nevertheless, the HEBD provides some evidence of debt monetization not evident when NFPD is used.

\section{Results for III/1972-IV/1983}

The results for the III/1972-III/1983 period, in which more emphasis was placed on the monetary aggregates, are reported in tables 5 and 6 . Conly the results with lags of inflation and output growth are rem ported.$^{31}$ These results indicate that, over this period,

\footnotetext{
3E When no lags of inflation and output growth are used, the results indicate unidirectional causality running from $\dot{\mathrm{M}} 1$ to $\mathrm{NFD}$ and independence between $M 1$ and HEBD.
} 


\section{Table 4}

\section{Signillcance Levels for Granger Causality Tests of M1 on HEBD for the 1/1960 III/1983 Period, with str lags of $P$ and $X$}

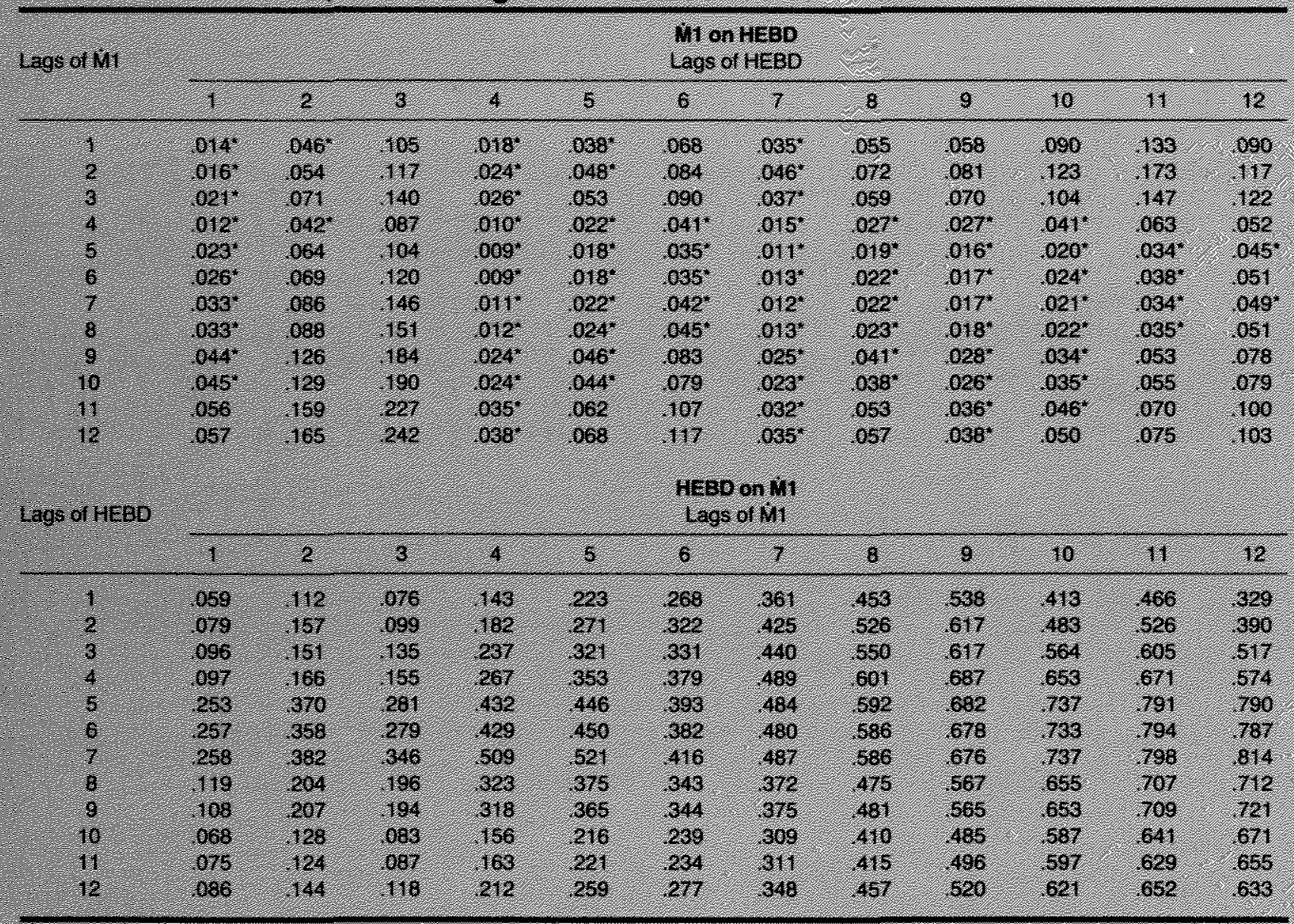

indicates significance at the 5 percent level

$\dot{M} 1$ is independent of both NFेD and the HEBD. There was no portion of the lag space considered in which the hypotheses constituting the Granger tests could be rejected. Hence, there is no evidence of debt monetization over this period for either measure of debt growth. Thus, the HEBD result, which indicates that the Federal Reserve had monetized the debt over the 1960-83 period, appears to result from the Federal Reserve's interest rate target procedures over nearly the first half of the period - a period when debt monetization is more likely to be an inherent result of attempts to influence interest rates. An investigation of a period for which it is more relevant to consider the question of debt monetization yields no evidence that the Federal Reserve has monetized the debt.

\section{CONCLUSIONS}

The purpose of this article was to clear up confusion that often characterizes discussions of debt monetization and to provide some evidence on the question of whether the Federal Reserve has monetized the debt. Specifically, it was pointed out that the phrase "monetizing the debt" means money growth in excess of that required to achieve some policy objective that is induced by rapid growth in the federal debt.

It was noted that the ratio of Federal Reserve debt holdings to net federal debt, or other such measures, cannot be used alone as evidence of debt monetiza tion. Changes in the money multiplier and factors that affect components of the monetary base will influence 
Table 5

Significance Levels for Granger Causality Tests for Mit and NFD for the III/1972-IV/1983 Period, with three lags of $\dot{P}$ and $\dot{X}$

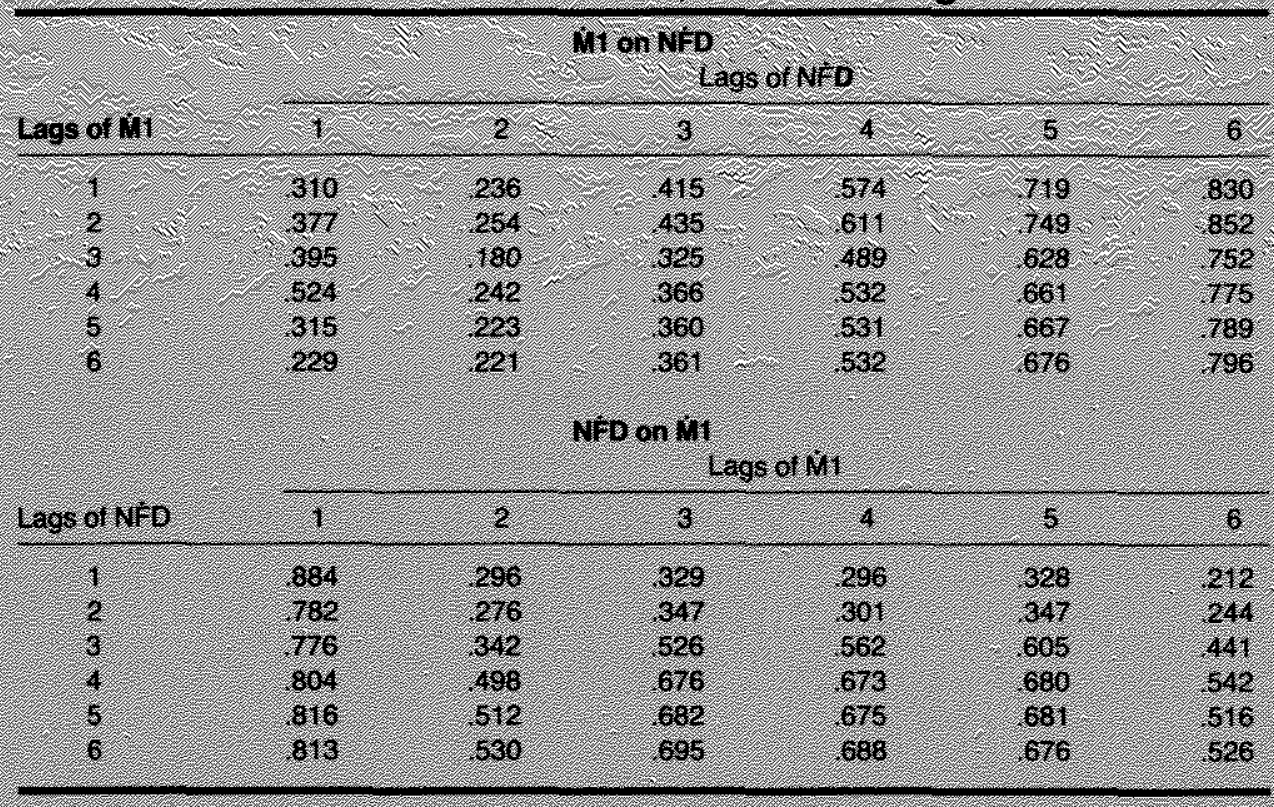

Table 6

\section{Significance Levels for Granger Causality Tests for M1 and} HEBD for the III/1972-II/1983 Period, with three lags of $\dot{P}$ and $\dot{X}$

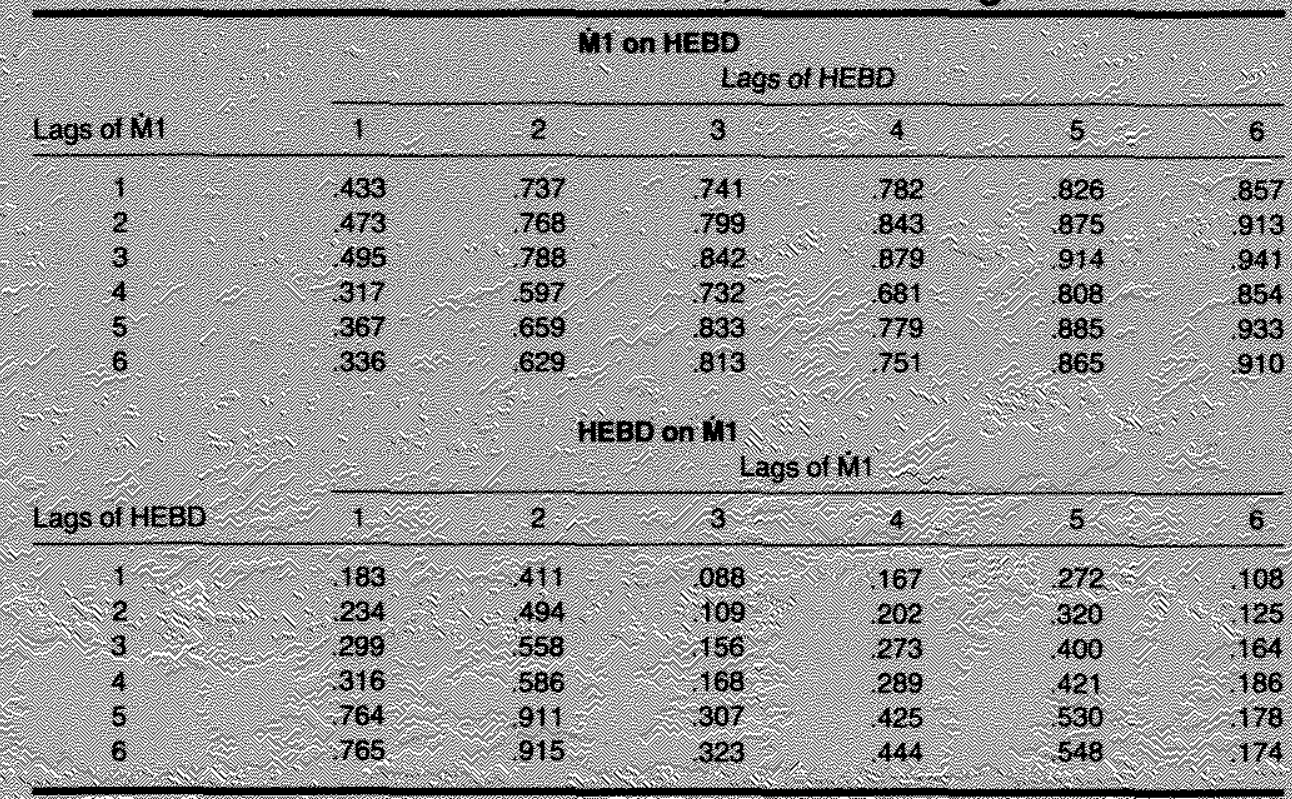


the growth of the Federal Reserve's portfolio of government securities for any given policy objective in ways that confound attempts to determine the extent of debt monetization taking place.

Two commonly used measures of debt growth, the growth of net federal debt and the high-employment budget deficit, were used to test whether money growth precedes debt growth, or vice versa. The results for the III/1972-IV/1983 period, during which the Federal Reserve placed more emphasis on the monetary aggregates than it had in previous years, shows no evidence of debt monetization by the Federal Reserve using either debt measure. For the entire 1960-83 period, there is evidence of debt monetization for the high-employment deficit measure, but not for growth of the net federal debt. Thus, the only evidence of debt monetization occurs during the period of interest rate targeting, when debt monetization is to be expected if increases in the federal debt put upward pressure on interest rates.

The reader is cautioned, however, in that actual money growth, rather than deviations of actual from desired money growth, was used in these tests. Since the debt monetization has to do with movements away from policy objectives induced by actual or perceived pressure of rapid debt growth on interest rates, the critical implicit assumption here, and in most previous studies of debt monetization, is that actual changes in money growth proxy such movements.

\section{REFERENCES}

Ahearn, Daniel S. Federal Reserve Policy Reappraised: 1951-1959 (Columbia University Press, 1963).

Allen, Stuart D., and Michael D. Smith. "Government Borrowing and Monetary Accommodation," Journal of Monetary Economics (November 1983), pp. 605-16.

Barth, James $\mathrm{R}_{\text {., }}$ George Iden and Frank S. Russek. "The Economic Consequences of Federal Deficits: An Examination of the Net Weaith and Instability Issues," processed (1984).

Barth, James R., Robin Sickles and Philip Wiest. "Assessing the Impact of Varying Economic Conditions on Federal Reserve Behavior," Journal of Macroeconomics (Winter 1982), pp. 47-70.

Batten, Dallas S., and Daniel L. Thornton. "How Robust Are the Policy Conclusions of the St. Louis Equation?: Some Further Evidence," this Review (June/July 1984), pp. 26-32.

Blinder, Alan S. "On the Monetization of Deficits," in Laurence $\mathrm{H}$. Meyer, ed., The Economic Consequences of Government Deficits (Kluwer-Nijhoff, 1983), pp. 39-73.

Board of Governors of the Federal Reserve System. "Announcements," Federal Reserve Bulletin (October 1974), pp. 740-41.

Brown, W. W. and G. J. Santoni. "Monetary Growth and the Timing of Interest Rate Movements," this Review (August/September 1983), pp. 16-25.

Carlson, Keith M. "Money Growth and the Size of the Federal Debt, "this Review (November 1984), pp. 5-16.
Darby, Michael R. "Some Pleasant Monetarist Arithmetic," Federal Reserve Bank of Minneapolis Quarterly Review (Spring 1984), pp. 15-20.

deLeeuw, Frank, and Thomas M. Holloway. "Cyclical Adjustment of the Federal Budget and Federal Debt," Survey of Current Business (December 1983), pp. 25-40.

Dewald, Willam G. "Deficits and Monetary Growth" Federal Reserve Bank of Atlanta Economic Review (January 1984), pp. 1120 .

Dwyer, Gerald P. "Money Creation and Federal Deficits," processed (1984).

Economic Report of the President, February 1983. (U.S. Government Printing Office, 1983).

Evans, Paul. "Do Large Deficits Produce High Interest Rates?" processed (1984).

Friedman, Milton, and Anna J. Schwartz. A Monetary History of the United States 1867-1960 (Pfinceton University Press, 1963).

Froyen, Richard T. "A Test of the Endogeneity of Monetary Policy," Joumal of Econometrics (July 1974), pp. 175-88.

Geweke, John, Richard Meese and Warren Dent. "Comparing Alternative Tests of Causality in Temporal Systems: Analytic Results and Experimental Evidence," Journal of Econometrics (February 1983), pp. 161-94.

Guilkey, David K, and Michael K. Salemi. "Small Sample Properties of Three Tests for Granger-Causal Ordering in a Bivariate Stochastic System," The Review of Economics and Statistics (November 1982), pp. 668-80.

Historical Statistics of the United States: Colonial Times to 1970, part 2. (GPO, 1975).

Horrigan, Brian R. "Pitfalls in Analyzing Deficits and Inflation," Federal Reserve Bank of Philadelphia Working Paper No. 83-4 (1983).

Horrigan, Brian R., and A. Protopapadakis. "Federal Deficits: A Faulty Gauge of Government's Impact on Financial Markets," Federal Reserve Bank of Philadelphia Business Review (March/April 1982), pp. 3-16.

Jacobs, Rodney L., Edward E. Leamer and Michaef P. Ward. "Difficulties with Testing for Causation," Economic Inquiry (July 1979). pp. 401-13.

Melvin, Michael. "The Vanishing Liquidity Effect of Money on Interest: Analysis and Implications for Policy," Economic inquiny (April 1983), pp. 188-202.

Sargent, Thomas J., and Neil Wallace. "Some Unpleasant Monetarist Arithmetic," Federal Reserve Bank of Minneapolis Quarterly Review (Fall 1981), pp. 1-17.

Tatom, John A. "A Perspective on the Federal Deficit Problem," this Review (June/July 1984), pp. 5-17.

"issues in Measuring An Adjusted Monetary Base," this Review (December 1980), pp. 11-29.

Thornton, Daniel L. "The Government Budget Constraint with Endogenous Money," Journal of Macroeconomics (Winter 1984), pp. $57-67$.

Thornton, Daniel L., and Dallas S. Batten. "Lag-Length Selection and Granger Causality Between Money and Income," Journal of Money, Credit and Banking (forthcoming, May 1985).

Wu, De-Min. "Tests of Causality, Predeterminedness and Exogeneity, "International Economic Review (October 1983), pp. 547-58.

Zellner, Arnold. "Causality and Econometrics," in Karl Brunner and Allan $\mathrm{H}$. Meltzer, eds., Carnegie-Rochester Conference Series on Public Policy, Volume 10 (Amsterdam: North-Holland 1979), pp. 9-54. 